Dossiê: Lutero e a Reforma - Artigo Original

\title{
Teologia Política em Martinho Lutero
}

\author{
Political Theology in Martin Luther
}

Wanderley Pereira da Rosa*

\begin{abstract}
Resumo
O texto Teologia Política em Martinho Lutero pretende apresentar a ética política luterana com base nos principais tratados do reformador alemão a esse respeito. Recorreremos também a especialistas e historiadores do pensamento luterano que o interpretam sob diferentes pontos de vista para fundamentarmos nossa posição. Identificaremos nos textos de Martinho Lutero, em primeiro lugar, um claro ataque à autoridade papal e da Cúria, e suas pretensões de soberania universal sobre todas as instâncias da vida. Demonstrar-se-á que Martinho Lutero parte desse duro ataque à autoridade papal e uma defesa intransigente da obediência à autoridade secular em seus primeiros anos, para uma posição distinta dessa. Esse primeiro posicionamento de Lutero era resultado de sua interpretação da Bíblia, especialmente de textos do Novo Testamento, como, por exemplo, Romanos 13 e Mateus 22:21. Em seu período mais maduro, Lutero passa a fazer uma defesa da resistência pacífica à autoridade injusta e daí, à resistência armada contra o tirano, quando este ameaçar a fé cristã.
\end{abstract}

Palavras-chave: Martinho Lutero; Teologia Pública; Pensamento Social e Político; Teoria Política.

\begin{abstract}
The text Political Theology in Martin Luther intends to present the Lutheran political ethics based on the main treatises of the German reformer in this respect. We will also rely on scholars and historians of the Lutheran thought, who interpret that in different points of view, in order to support our position. In Martin Luther's writings we shall first identify a clear attack on papal authority and the Roman Curia, and their pretensions to universal sovereignty over all instances of life. It will be demonstrated that Martin Luther departs from this harsh attack on papal authority and an uncompromising defense of obedience to secular authority in his earliest years, to a position distinct from that. This first positioning of Luther was a result of his interpretation of the Bible, especially New Testament texts such as Romans 13 and Matthew 22:21. In his more mature period, Luther begins to make a defense of peaceful resistance towards the unjust authority and hence, to armed resistance against the tyrant, when this tyrant threatens the Christian faith.
\end{abstract}

Keywords: Martin Luther; Public Theology; Social and Political Thought; Political Theory.

Artigo submetido em 17 de maio de 2016 e aprovado em 09 de dezembro de 2016.

* Doutor em Teologia pela PUC/RJ (2015) e Mestre em Teologia Prática pela Escola Superior de Teologia de São Leopoldo/RS (2010). Membro da SOTER - Sociedade de Teologia e Ciências das Religião é também o Editor Responsável pelas publicações da Editora Unida. País de Origem: Brasil. E-mail: wanderley@faculdadeunida.com.br

Horizonte, Belo Horizonte, v. 14, n. 44, p. 1210-1229, out./dez. 2016 - ISSN 2175-5841 


\section{Introdução}

Ainda que o foco de Martinho Lutero estivesse na cristologia e na justificação pela fé, ao perguntarmos pela teologia política luterana, obras como $\grave{A}$ Nobreza Cristã da Nação Alemã Acerca da Melhoria do Estamento Cristão (1520), Da Autoridade Secular, até que ponto se lhe deve obediência (1523) e o Debate Circular Acerca do Direito de Resistência ao Imperador (1539) se destacam¹. A teoria política de Lutero precisa ser entendida a partir de seu contexto. Deve-se considerar, ainda, que seu pensamento foi evolutivo e passou por importantes transformações ao longo de sua vida. No que diz respeito a esse ponto específico de suas reflexões, é importante também não esquecer que, de 1521 até 1546, o ano de sua morte, Lutero viveu com direitos políticos e eclesiásticos cassados (DREHER, 2006, p. 160). Portanto, seu pensamento político reflete, pelo menos em parte, sua própria situação.

Assim, suas afirmações e conclusões quanto a uma ética política são contextuais. São reações a situações históricas específicas e expressam os limites contingenciais próprios da época. Por exemplo, se no mundo moderno o Estado democrático representa a autoridade e detém o uso legítimo da força, para Lutero esta autoridade é entendida em termos pessoais e não institucionais (DREHER, 2006, p. 161). Nesse caso, Lutero dá continuidade ao pensamento político da Idade Média, quando o governante era visto como autoridade por direito divino. Contudo, para Martinho Lutero a investidura do governante era por graça divina e nada tinha a ver com a igreja. Nisso há descontinuidade com o pensamento medieval. Além disso, ele reconhece a autoridade divina do governante, mas rejeita sua divinização. A esse respeito, o historiador luterano Martim Dreher afirma: "Como para ele a autoridade do governante vem de cima e não tem sua legitimação

\footnotetext{
${ }^{1} \mathrm{O}$ texto privilegiou obras de Martinho Lutero nas quais ele abordou sua visão acerca da relação dos cristãos com o Estado e o papel do Estado, propriamente dito. Essas são obras primárias, essenciais para a proposta do artigo. Foram utilizadas e se encontram discriminadas nas referências no final do artigo as edições em português da Editora Sinodal, que contam com boas introduções de especialistas brasileiros no pensamento de Lutero.
} 
em si mesma, sendo, pois, dependente, não há obediência cega, ilimitada em relação ao governante." (DREHER, 2006, p. 161).

Mas, devemos insistir, Lutero ainda vive no mundo da Cristandade, sua mentalidade se guia ainda pelas categorias do Corpus Christianum. Ele não conhece a separação entre Igreja e Estado do mundo moderno. Seu pensamento político se baseia na ideia da existência dos dois reinos de Cristo na terra: o da Palavra e o da Espada (JUNGHANS, 2001, p. 50, 51). É nesse mundo da Cristandade que Lutero reflete sobre os limites da autoridade secular e da possibilidade de resistência civil a essa autoridade (DREHER, 2006, p. 162).

\section{Justificações teológicas do jovem Lutero acerca da autoridade secular}

Se o jovem Lutero resiste em apoiar qualquer desobediência às autoridades civis, o mesmo não pode ser dito em relação às autoridades eclesiásticas. Em um dos seus primeiros e mais importantes escritos ele faz duro ataque à Cúria e à estrutura episcopal que governava a Igreja. Nessa obra, À Nobreza Cristã da Nação Alemã, ele mira em três "muralhas”, segundo ele, erguidas pela Cúria (ALTMANN, 1994, p. 188-190). Em primeiro lugar, critica o argumento segundo o qual a sociedade está dividida entre o espiritual e o secular e que, nessa relação, o eclesiástico estaria acima do secular (LUTERO, 2000a, p. 281). Portanto, o poder civil não teria autoridade para punir ou governar os membros do clero. Para ele, a separação entre espiritual e secular "é uma invenção e fraude muito refinada" e “todos nós somos ordenados sacerdotes através do Batismo.” (LUTERO, 200oa, p. 282). Assim, Lutero afirma que aqueles que ocupam o poder secular, sendo batizados como qualquer pessoa, são também sacerdotes e seu ofício "pertence à comunidade cristã e lhe é útil” (LUTERO, 2000a, p. 283). Ora, se aos chamados clérigos é outorgada a administração da Palavra e dos sacramentos ("esta é sua ocupação e seu ofício"), a "autoridade secular tem a espada e o açoite na mão para com eles punir os maus e proteger os bons” (LUTERO, 2000a, p. 284). Sua conclusão é que se o poder secular é ordenado por Deus, como qualquer outra 
profissão, "deve-se deixar que seu ofício passe livre e desimpedidamente por todo o corpo da cristandade, sem acepção de pessoas, atinja ele o papa, bispo, padres, monges, freiras ou a quem for.” (LUTERO, 2000a, p. 284).

Em segundo lugar, ele ataca a pretensão de caber somente ao papa a interpretação das Escrituras. Para Lutero, nada é apresentado pela Cúria que sustente tal ideia, "é uma fábula desaforadamente inventada. Eles não podem apresentar sequer uma letra para provar que só o papa pode interpretar a Escritura ou confirmar sua interpretação" (LUTERO, 2000a, p. 286). Para Lutero a Igreja Cristã não pode ser reduzida "a uma única pessoa". E, se todos somos sacerdotes, como ele acabara de argumentar, "como não haveríamos de ter também o poder de perceber e de julgar o que seria correto ou incorreto na fé?” (LUTERO, 2000a, p. 287).

E, em terceiro lugar, Martinho Lutero critica a afirmação segundo a qual somente o papa pode convocar concílios. O reformador argumenta com exemplos históricos, citando o Concílio de Jerusalém (Atos 15), convocado, segundo ele, por todos os apóstolos e anciãos, e não somente por Pedro, e o Concílio de Nicéia (325 d.C.), convocado pelo imperador Constantino. Assim, "quando a necessidade o exigir e o papa se tornar um escândalo para a cristandade, quem primeiro puder deve, como membro fiel do corpo inteiro, contribuir para que se realize um concílio livre de fato." E, continua Lutero, "ninguém pode fazer isso melhor que a espada secular, principalmente por serem também co-cristãos, co-sacerdotes, co-clérigos, co-competentes em todas as coisas." (LUTERO, 2000a, p. 288). ${ }^{2}$

Esse texto de 1520 expande e aprofunda alguns dos argumentos que Martinho Lutero já havia usado em suas 95 teses de 1517. Na tese 79 ele afirma: "É blasfêmia dizer que a cruz com as armas do papa, insignemente erguida, equivale à

\footnotetext{
${ }^{2}$ Lutero conclui essa primeira parte de seu texto com palavras duras, como era próprio de sua lavra: “Com isso, espero, está derrubado o falso e mentiroso terror com que os romanos [i.e., os seguidores do papa], por longo tempo, fizeram nossas consciências tímidas e temerosas. [Espero também que esteja claro] que eles estão sujeitos à espada da mesma forma como todos nós, que não têm o poder de interpretar a Escritura por puro poder, sem conhecimento, que não têm poder de impedir um concílio ou de limitá-lo arbitrariamente, forçá-lo ou tirar-lhe a liberdade, e que onde o fizeram são verdadeiramente a comunidade do anticristo e do diabo, de Cristo nada têm senão o nome." (LUTERO, 2000a, p. 289).
} 
cruz de Cristo." E completa, na tese 80: “Terão que prestar contas os bispos, curas e teólogos que permitem que semelhantes conversas sejam difundidas entre o povo.” (LUTERO, 1987, p. 28). Para o reformador torna-se difícil defender a dignidade do papa diante das perguntas do povo. "Por exemplo, por que o papa não evacua o purgatório por causa do santíssimo amor e da extrema necessidade das almas - o que seria a mais justa de todas as causas -, se redime um número infinito de almas por causa do funestíssimo dinheiro para a construção da basílica - que é uma causa tão insignificante?” (tese 82) (LUTERO, 1987, p. 28). “Do mesmo modo: por que o papa, cuja fortuna hoje é maior que a dos mais ricos Crassos, não constrói com seu próprio dinheiro ao menos esta uma Basílica de São Pedro, ao invés de fazê-lo com o dinheiro dos pobres fiéis?” (tese 86) (LUTERO, 1987, p. 29). Sua postura crítica, algo ácida, contra a pompa e o poder papal e da Cúria já se fazia sentir em 1517.

Lutero ataca a autoridade papal, mas quer preservar a autoridade secular. (BURGARD, 2013, p. 297). Não percebe, no entanto, que ao confrontar a autoridade papal, abre caminho para questionamentos de toda sorte a qualquer autoridades. O sistema baseado no binômio trono-altar já não poderia se sustentar. O Corpus Christianum estava emparedado. Lutero ajudara, sem o perceber, a abrir a caixa de Pandora medieval. Em seu famoso escrito, também de 1520, Sobre a Liberdade Cristã, logo na introdução, o reformador pronuncia duas das suas frases mais famosas. A primeira: "O cristão é um senhor libérrimo sobre tudo, a ninguém sujeito". A segunda, imediatamente posterior: "O cristão é um servo oficiosíssimo de tudo, a todos sujeito." (LUTERO, 200ob, p. 435). Martin Dreher, a esse respeito, afirma que "essa segunda tese não foi ouvida. Dela nada se queria saber." (DREHER, 2014, p. 149). Tudo o que se quis daí em diante foi alcançar a liberdade e a emancipação do sujeito.

\footnotetext{
${ }^{3}$ Ao analisar as afirmações de Lutero na obra À Nobreza Cristã da Nação Alemã sobre as três muralhas que devem ser derrubadas, o historiador Martin Dreher afirma que esta é "uma declaração da maioridade do ser humano em sua responsabilidade. Para Lutero, a maioridade e responsabilidade dizem respeito ao âmbito religioso." Após esta afirmação, Dreher reconhece que "as influências de sua iniciativa, contudo, foram muito além. Provocou brigas e discussões que persistiram durante séculos no que denominamos de Modernidade, gerando novos tipos de excomunhão, castigos e exílios." Este historiador aponta, em sua conclusão, para a participação de Lutero nesse processo de desconstrução da autoridade baseada no trono e altar. (DREHER, 2014, p. 143, 144). Ver também Marc Lienhard para quem o resultado desta obra de Lutero seria ambíguo, pois "algumas pessoas iriam assumir as reformas sociais e políticas propostas por Lutero e negligenciariam o que para ele era o essencial, a saber, uma volta da cristandade à Sagrada Escritura e à fé." (LIENHARD, 1998, p. 83).
} 
Se suas críticas ao papa e à estrutura episcopal não deixam dúvidas sobre a necessidade de desobediência à tirania papal, sua postura ante a autoridade secular, muitas vezes tirânica, não é tão firme (LUTERO, 1996d, p. 102)4. Para Lutero, as classes populares não devem se revoltar contra o imperador ou os governantes locais. Se houver revolta, deverá ser apenas uma "revolta espiritual”. Segundo ele, "os que lêem e compreendem corretamente minha doutrina não fazem revolta. Não o aprenderam de mim.” (LUTERO apud DREHER, 2006, p. 163).

Em seu escrito Da Autoridade Secular de 1523, ele expõe seu pensamento acerca dos limites da obediência e da desobediência civil. Segundo o próprio Lutero, se no escrito de 1520 ele orientou a nobreza cristã sobre o que ela deveria fazer, neste ele se concentraria em orientar-lhes sobre "o que não devem fazer." (LUTERO, 1996d, p. 81). Inicia Lutero em tom crítico aos governantes: "Pois Deus, o onipotente, enlouqueceu os nossos príncipes, de sorte que pensam poderem fazer e ordenar a seus súditos o que quiserem;" e completa, “e também os súditos se enganam, quando crêem estarem obrigados a cumprir tudo isso plenamente. Agora até começaram a ordenar ao povo que entreguem livros." (LUTERO, 1996d, p. 81). $\mathrm{O}$ alerta de Lutero era uma reação às ordens de alguns governantes para que fossem confiscadas cópias do Novo Testamento publicadas pelo reformador em setembro de 1522 e de outros escritos seus anteriores a esta data, ou proibida a sua leitura5. Nesse caso, os súditos deveriam desobedecer: "Tenho que resistir-lhes, pelo menos com palavras" (LUTERO, 1996d, p. 82). Do contrário, o cristão estaria negando a Deus.

\footnotetext{
4 Este é o teor, por exemplo, do texto escrito por Lutero em 6 de março de 1530 intitulado Um Conselho do Doutor Martinho Lutero se é permitido resistir com razão ao imperador se ele quer usar de violência contra alguém por causa do Evangelho: "Mas, segundo a Escritura, de forma alguma convém que alguém (que queira ser cristão) resista à sua autoridade superior não vindo ao caso se esta procede justa ou injustamente; o cristão deve, muito antes, suportar a violência e a injustiça, particularmente da parte de sua autoridade superior. Pois mesmo que Sua Majestade proceda injustamente e transgrida sua obrigação e juramento, isto não anula sua autoridade imperial e a obediência de seus súditos, enquanto o império e os príncipes-eleitores o considerarem imperador e não o destituírem. (LUTERO, 1996g, p. 134-135).

5 “Em março de 1522, o duque Guilherme IV da Bavária proibira, num primeiro de uma série de despachos religiosos, a todos os seus súditos a leitura e discussão dos livros de Lutero. O duque Jorge da Saxônia publicou ordem semelhante a seus oficiais em fevereiro de 1520." (LUTERO, 1996d, p. 81, nota de rodapé 9). Este mesmo duque ordenou, em novembro de 1522, a entrega de todas as cópias do Novo Testamento em troca do preço pago por ele. (LUTERO, 1996d, p. 82, nota de rodapé 10).
} 


\section{Lutero e o movimento camponês}

Parte de sua posição transigente com a autoridade secular, mesmo se tirânica, decorre de sua reação contrária ao uso político de suas posições teológicas acerca da autoridade papal, notadamente pelo movimento camponês na Alemanha. Nesse contexto, Tomás Müntzer aparece como um dos seus principais desafetos. Inicialmente adepto da causa luterana, chegando a ser indicado por Lutero para pregador na cidade de Zwickau, Müntzer rompeu com o reformador de Wittenberg, dentre outras questões, por discordar da posição submissa de Lutero em relação aos governantes (DREHER, 2013, p. 286, 287; MCGRATH, 2012, p. 70; LIENHARD, 1998, p. 130, 131). Para Tomás Müntzer, o estabelecimento do Reino de Deus aniquilava toda ordem secular, uma vez que o Espírito Santo igualava todos, numa sociedade sem classes e sem hierarquia. Para ele, o povo deveria recorrer ao uso da força se fosse preciso, para que isso se tornasse uma realidade (MCGRATH, 2012, p. 70).

Contra Müntzer e seus seguidores, Lutero escreveu uma Carta aos Príncipes da Saxônia sobre o Espírito Revoltoso, em 1524. Martinho Lutero afirma que a autoridade secular deveria e poderia recorrer ao uso da força contra a violência dos revoltosos. Sem citar o nome de Müntzer, Lutero diz ter ouvido que "esse espírito não irá contentar-se com palavras, mas pretende usar a força e se opor à autoridade com violência, e organizar para tanto uma verdadeira rebelião.” (LUTERO, 1996c, p. 289-290). Diante disso, Lutero convoca o governante para que "coíba essa tolice e se antecipe à rebelião”. E continua: “Pois V. A. P. sabe perfeitamente que seu poder e autoridade secular lhe foram confiados por Deus a fim de preservar a paz e castigar os perturbadores, como Paulo ensina em Romanos 13.” Por isso, Lutero alerta a autoridade que "Deus vai cobrá-lo e exigir prestação de contas sobre o uso permissionário e a seriedade da espada confiada.” (LUTERO, 1996c, p. 290).

Os movimentos sociais em curso entre o campesinato alemão desembocaram na Guerra dos Camponeses de 1524/25. A atitude de Martinho 
Lutero perante essa revolta popular configura-se como um dos episódios mais polêmicos que envolvem a vida do reformador de Wittenberg (ALTMANN, 1994, p. 39) ${ }^{6}$. Inicialmente ele fez uma tentativa de moderação e conciliação entre os nobres e os camponeses como podemos ler em seu Exortação à Paz: Resposta aos Doze Artigos do Campesinato da Suábia (LUTERO, 1996f) 7. Sua posição, no entanto, ficou mais conhecida pelo escrito Adendo: Contra as Hordas Salteadoras e Assassinas dos Camponeses, de $1525^{8}$. Para Lutero, os camponeses se tornaram triplamente culpados e por isso "mereceram a morte múltiplas vezes, tanto do corpo como da alma." Seu primeiro pecado foi a desobediência à autoridade. E, assim, "como negam essa obediência de forma intencional e atrevida e se opõem a seus senhores, eles comprometeram corpo e alma, como costumam fazer os patifes e os safados infiéis, mentirosos, perjuros e desobedientes" (LUTERO, 1996a, p. 332). Em segundo lugar, eles promoveram a rebelião. E, para Lutero, a rebelião devasta todo país. Por isso, "quem puder deve esmagar, matar e sangrar, sigilosa ou publicamente, e estar lembrado de que não pode haver coisa mais venenosa, prejudicial e diabólica do que uma pessoa rebelada.” E, por último, eles abusaram do Evangelho, com o que "se tornam os maiores blasfemadores e sacrílegos de seu santo nome, louvando e servindo o diabo sob as aparências do Evangelho, pelo que merecem dez vezes a morte em corpo e alma, pois nunca ouvi falar de pecado mais abominável." (LUTERO, 1996a, p. 333). Para fundamentar sua posição, Lutero recorre insistentemente à citação de textos bíblicos como Lucas 20.25 ("Dai a César o que é de César"), Romanos 13 ("Todo homem esteja sujeito às autoridades superiores") e I Pedro 2.13 ("Sujeitai-vos a toda instituição humana”). Altmann

\footnotetext{
${ }^{6}$ Para uma leitura sobre as divergências de opinião em torno dessa questão sugerimos o texto de Marc Lienhard (LIENHARD, 1998, p. 357-370). Há aqueles, por exemplo, que defendem uma distinção entre Reforma e Guerra dos Camponeses. A tendência, contudo, entre os historiadores é reconhecer em Lutero, no mínimo, um papel "catalisador" (LIENHARD, 1998, p. 358). A questão é que com o princípio teológico que advoga o "sacerdócio universal", Lutero colocou em evidência os direitos do leigo numa sociedade fundamentada no cristianismo. Como afirma Marc Lienhard, este princípio "tornou relativa a hierarquia, e esta foi até mesmo suprimida (LIENHARD, 1998, p. 359, 360). Após apresentar diversas opiniões acerca da atitude de Lutero frente à revolta, Lienhard concorda que ele via a necessidade de "descolar" a Reforma da causa camponesa, caso contrário, esta sofreria um duro golpe. (LIENHARD, 1998, p. 364-366).

${ }^{7}$ Lutero viajou pela Turíngia, um dos centros da revolta popular, e escreveu esse texto de cores irenistas motivando uma reconciliação entre as partes. (1996f, p. 304-329). Entretanto, ao perceber que seu movimento poderia ser engolfado pelas Revoltas Camponesas, ele partiu para o ataque, como pode ser visto em Contra as Hordas Salteadoras e Assassinas... . (LIENHARD, 1998, p. 366).

${ }^{8}$ Não devemos nos esquecer que, quando o texto foi publicado, a guerra já havia terminado e a tragédia estava consumada (ALTMANN, 1994, p. 251).
} 
conclui que, ao fim e ao cabo, “os príncipes sentiram-se legitimados, os camponeses traídos e até mesmo os amigos mais próximos de Lutero não conseguiram ocultar sua decepção e escândalo”. (ALTMANN, 1994, p. 251. Também RANDELL, 1995, p. 63). Lutero jamais se desculpou. (LIENHARD, 1998, p. 364).

Como já foi demonstrado, para Martinho Lutero o poder secular foi posto por Deus para coibir o mal e promover o bem (p. 3. Cf. ALTMANN, 1994, p. 38; ZWETSCH, 2016, p. 7, 8, 11). Ao lado deste, há o regime espiritual "que cria cristãos e pessoas justas através do Espírito Santo". (...) "Pois sem o regime espiritual de Cristo ninguém pode ser justificado perante Deus por meio do regime secular”. (LUTERO, 1996d, p. 86-87). Sua visão a esse respeito decorre de sua antropologia teológica e de sua soteriologia. Para ele, o ser humano é mau em sua natureza. Herdeiro do pecado original, esse ser humano sempre se inclinará para o pecado. Isso só não aconteceria se todos fossem verdadeiros cristãos. Nesse caso, "não seriam necessários nem de proveito príncipe, rei ou senhor, nem espada nem lei." Contudo, "nenhum ser humano é cristão e justo por natureza, mas todos são pecadores e maus". Então, para coibir a maldade no mundo, Deus providenciou um caminho de salvação em Cristo e Seu Reino, e um caminho de controle social pela espada secular (1996d, p. 84-86). Sua posição inicial era absolutamente contrária a qualquer rebelião contra a autoridade constituída.

\section{Mudanças na teologia política de Lutero no decênio de 1530}

Nos anos seguintes, contudo, Martinho Lutero modificaria algumas de suas antigas teses. Uma ameaça real à sobrevivência do luteranismo se esboçou no horizonte, quando em março/abril de 1529 o Imperador Carlos V, após derrotar Francisco I da França, conseguiu que a Dieta de Espira ordenasse a recatolização dos territórios alemães luteranos. Foi contra essa decisão que protestaram os estamentos luteranos em 19 e 20 de abril, surgindo daí a expressão "protestantes" (DREHER, 2013, p. 241). A Dieta, tendo ignorado o protesto dos príncipes 
luteranos, determinou que o Edito de Worms fosse imediatamente posto em prática, se necessário, pela força. A desobediência à decisão da Assembleia poderia acarretar um ataque militar das tropas imperiais. Uma interpretação jurídica embasou a legalidade de uma eventual desobediência às decisões da Assembleia. Nesse caso, uma resistência armada seria considerada legítima defesa. A iniciativa dessa consulta jurídica partiu de Filipe de Hesse, nesse momento o príncipe alemão mais engajado na causa luterana. Filipe de Hesse, baseado nesses argumentos jurídicos, sustentou que a autoridade divina dos governantes engloba todos: não apenas o imperador, mas também os príncipes territoriais. Decorre daí que todos esses governantes, dos maiores aos menores, têm a obrigação divina de defender os súditos. A esse respeito Quentin Skinner explica que "se o imperador ultrapassar os limites de seu cargo perseguindo o Evangelho ou tratando com violência qualquer um dos príncipes, estará violando as obrigações a ele impostas por ocasião de sua eleição, sendo, portanto, legítimo combatê-lo." (SKINNER, 2009, p. 472).

Respondendo a uma consulta feita por João, o príncipe-eleitor da Saxônia, acerca das opiniões de Filipe de Hesse, Lutero baseou-se no Novo Testamento e insistiu na antiga posição conservadora e passiva, no que tange à obediência às autoridades:

Mas, segundo a Escritura, de forma alguma convém que alguém (que queira ser cristão) resista à sua autoridade superior não vindo ao caso se esta procede justa ou injustamente; o cristão deve, muito antes, suportar a violência e a injustiça, particularmente da parte de sua autoridade superior. Pois mesmo que Sua Majestade proceda injustamente e transgrida sua obrigação e juramento, isto não anula sua autoridade imperial e a obediência de seus súditos, enquanto o império e os príncipes-eleitores o considerarem imperador e não o destituírem. Afinal de constas, o imperador ou o príncipe que agir contra todos os mandamentos de Deus não deixa de ser imperador e príncipe, tendo para com Deus obrigação e juramento muito mais elevados do que para com as pessoas humanas. Se fosse permitido resistir à Majestade Imperial quando ela agisse injustamente, então se poderia fazer-lhe oposição todas as vezes que ela proceder contra Deus; desta forma não restaria certamente autoridade nem obediência alguma no mundo, porque qualquer súdito poderia alegar este pretexto de que sua autoridade superior estaria praticando injustiça contra Deus. (LUTERO, 1996g, p. 134-135). 
A preocupação de Martinho Lutero era com a observância do Novo Testamento, conforme ele o interpretava, e com a ordem pública. Ele temia o caos social. Por isso, quanto ao imperador, "ninguém deve negar-lhe obediência ou opor-se a ele. Pois isto é rebelião, é começar o tumulto e a discórdia.” (LUTERO, 1996g, p. 135).

Quando o Imperador Carlos V retornou à Alemanha em 1530 para a Assembleia de Augsburg, estava decidido a aplicar finalmente as decisões do Edito de Worms de 1521 que visava erradicar o luteranismo dos seus domínios. Após os luteranos apresentarem a Confissão de Augsburg redigida por Filipe Melanchthon, e a Assembleia rejeitá-la, exigindo a restauração da antiga situação eclesiástica, houve nova ameaça à causa luterana. Novamente Filipe de Hesse retomou seus argumentos a favor da resistência armada para defender a formação de uma aliança defensiva por parte dos príncipes luteranos. Desta feita, ele recebeu o apoio de João da Saxônia que, por sua vez, também recorreu a consultas jurídicas sobre o caso. A interpretação jurídica resultante qualificou esse possível ataque do imperador como “injustiça notória”. (SKINNER, 2009, p. 474, 478).

Diante desse novo cenário, Lutero e seus companheiros foram pressionados a reconsiderar as antigas posições políticas. Em consequência disso, no final de outubro de 1530, Lutero, Melanchthon, Spalatin e outros capitularam e se mostraram dispostos a endossar os argumentos apresentados. Em conferência convocada por João da Saxônia para debater o assunto, Lutero e seus colegas redigiram e assinaram um documento afirmando ser coisa do passado que "até agora tenhamos ensinado a não resistir em absoluto à autoridade do governo”, alegando que "não sabíamos que a própria lei da autoridade dirigente admite o direito da resistência armada” (SKINNER, 2009, p. 475). E Quentin Skinner finaliza: “Assim, concluem que, então 'nesse caso é necessário lutar, mesmo se o próprio imperador nos atacar."' (SKINNER, 2009, p. 475).

Martinho Lutero reiterou esse novo posicionamento em ocasiões posteriores. Já em abril de 1531, havia sido publicado o texto Advertência do Dr. 
Martinho Lutero a seus Estimados Alemães. Nesse novo tratado, Lutero antevê a possibilidade de uma guerra provocada pelos católicos. Argumenta que eles, os luteranos, como eram "xingados", não deram motivo para isso. Ao contrário, “oramos e clamamos sempre e sem cessar por paz." (LUTERO, 1996b, p. 487). Assim, "ninguém nos pode culpar pela guerra ou por algum tumulto, nem diante de Deus nem diante dos homens". Mas, afirma sem vacilar, "vamos enfrentar as coisas com confiança e estar preparados para o que vier: seja guerra ou tumulto, como a ira de Deus o decidir." Mostra-se disposto a lutar: "se for assassinado neste tumulto papista e clerical, quero levar comigo um monte de bispos, padres e monges, de maneira que se dirá que o doutor Martinho foi levado à sepultura acompanhado de uma grande procissão..." (LUTERO, 1996b, p. 488). Afirma também que não recriminará quem resistir aos ataques das tropas católicas: "Não quero ter recriminado nem permitirei que se recrimine como sedicioso o partido que se opuser aos assassinos e sanguinolentos papistas; quero aceitar que o chamem de defesa própria". E vaticina: "Pois no caso em que os assassinos e algozes querem guerrear e matar a todo custo, certamente não é revolta opor-se a eles e defenderse." (LUTERO, 1996b, p. 491).

Logo após esses acontecimentos, no início de 1531, os evangélicos fizeram uma aliança com o objetivo de se proteger mutuamente: a Liga Esmalcalde. Houve, no entanto, entendimentos de ambos os lados e, em 1532, firmaram a trégua de Nürnberg até que uma Assembleia Geral decidisse essas questões (FISCHER, 1996, p. 214). A ameaça se fez sentir novamente em fins de 1538 e início de 1539, depois que o papa Paulo III convocou um concílio para o ano de 1537. Os luteranos achavam que a trégua de Nürnberg seria rompida. Mais uma vez Lutero se manifestou sobre a posição do cristão ante a autoridade secular. O teólogo luterano Joachim H. Fischer, a esse respeito, concluiu que "Lutero continuou convicto de que ao cristão não é permitido opor-se à autoridade superior legítima quando esta o perseguir por causa de sua fé". E, ele continua, "Mas numa guerra contra os evangélicos, com a finalidade de acabar com a pregação do Evangelho, o imperador não seria tal autoridade constituída." (FISCHER, 1996, p. 215). 
Essa nova posição de Martinho Lutero reaparece nas 91 teses que ele preparou no texto conhecido como Debate Circular Sobre Mt 19.21, de 1539. Esses argumentos de Lutero, agora mais incisivos, se baseiam na ideia de ser o papa o verdadeiro responsável por esses ataques. O imperador seria somente um auxiliar secular. Ora, se o papa não era uma autoridade legítima, a resistência seria possível. Na tese 66 ele afirma que “(...) se o papa promover uma guerra, deve-se resistir-lhe como se fosse um monstro furioso e possesso, ou um verdadeiro ursolobo.” E continua, “pois ele não é bispo, nem herético, nem príncipe, nem tirano, mas uma fera que devasta a tudo, como diz Daniel." (tese 67). E mais, "não importa se ele tem a seu serviço príncipes, reis ou os próprios imperadores, encantados pelo título da Igreja." (tese 68). Ainda na tese 70 afirma que "também o fato de se jactarem de serem defensores da Igreja não salva os reis, príncipes, nem os imperadores, pois é sua obrigação saber o que é a Igreja.” (LUTERO, 1996e, p. 221222).

Como visto acima, a ética política de Martinho Lutero sofre alterações ao longo do tempo como reflexo da própria evolução e expansão do movimento da Reforma9. Assumindo isso, devemos analisar as implicações de tal teoria. Quentin Skinner sugere que são duas as implicações políticas decorrentes de sua teologia e que elas expressam aquilo que há de mais distintivo e influente em seu pensamento acerca desse tema. Em primeiro lugar, Skinner destaca que Lutero "assume um claro compromisso de repudiar a ideia segundo a qual a Igreja possui poderes de jurisdição, e por isso detém autoridade para dirigir e regular a vida cristã." (SKINNER, 2009, p. 294). Ora, isso se evidencia nas duras críticas feitas por Lutero à prática, tão disseminada em seus dias, da venda de indulgências pela Igreja. Essa prática religiosa, que ganhara contornos de escândalo, sustentava-se na doutrina segundo a qual a Igreja detinha a autoridade, por meio dos sacramentos, para conceder ou não a salvação aos indivíduos. Martinho Lutero

\footnotetext{
${ }^{9} \mathrm{O}$ famoso historiador francês Lucien Febvre tem opinião distinta dessa. Ele defende que houve, isto sim, uma retração de Lutero nos anos de 1530. Lutero teria sido, segundo Febvre, mais aguerrido e insurgente contra a utoridade secular em sua juventude e, com o passar dos anos, foi-se acomodando e defendendo mais a submissão às autoridaes e a ordem social. (FEBVRE, 2012, p. 287-297).
} 
ataca ferozmente aquilo que ele considera uma falsa autoridade do papa e de toda a estrutura episcopal em escritos como as Noventa e Cinco Teses e À Nobreza Cristã da Nação Alemã, dentre outros. Sua doutrina do sacerdócio universal, de caráter teológico, ganhará contornos de conquista social na medida em que põe em cheque a ideia de que o clero constitui uma classe especial, "com jurisdições e privilégios específicos." (SKINNER, 2009, p. 295).

Além disso, em Da Autoridade Secular, fica patente o repúdio do reformador às pretensões eclesiásticas de poder temporal. Para ele a Igreja é uma congregatio fidelium e deve se limitar a isso. Skinner alerta para o perigo da interpretação equivocada da tese luterana dos dois $\operatorname{reinos}^{10}$. De fato, o cristão é súdito de ambos os regimes. Mas, pondera Skinner:

De modo geral, porém, resulta suficientemente claro que, ao discutir o poder no reino espiritual, Lutero tem em mente uma forma de governo puramente interna, "um governo da alma", sem nenhuma relação com os assuntos temporais, e inteiramente dedicado a socorrer os fiéis no rumo da salvação. (SKINNER, 2009, p. 296).

Portanto, toda pretensão papal de exercer poder temporal deve ser considerada uma tentativa de usurpação do que é próprio tão somente das autoridades seculares. Essa primeira implicação do pensamento político de Lutero ajuda a preparar o caminho para a separação moderna entre Igreja e Estado, não obstante os limites históricos de tal pensamento, aos quais já aludimos em nossa introdução.

A segunda implicação destacada por Skinner tem a ver com a "defesa correspondente das autoridades seculares", como forma de preencher o vazio de poder criado com a desconstrução das pretensões papais de poder temporal. Ora, sendo a Igreja somente uma congregatio fidelium, decorre daí que as autoridades seculares detêm o uso exclusivo dos canais coercitivos, "inclusive sobre a própria

\footnotetext{
${ }^{10}$ Esse famoso conceito teológico luterano tem sofrido seguidas interpretações equivocadas ao longo da história. Basicamente, estes equívocos entendem que Lutero está propondo uma separação entre o Reino de Deus e o Reino secular em termos dualistas. Um bom texto que faz análise dessas interpretações é Os Dois Reinos de Ulrich Duchrow. Duchrow mostra, dentre outras coisas, que o pensamento do Reformador é multidimensional e complementar. (DUCHROW, 1987; ver também ZWETSCH, 2016, p. 11).
} 
Igreja”. Assim, Lutero desmonta a luta travada na Idade Média entre o regnum e o sacerdotium como dois poderes paralelos e universais. Doravante, o governo das nações pertence somente à autoridade secular, que sobre todos exerce esse direito (SKINNER, 2009, p. 296-297). Aqui Lutero se divide, ora estabelecendo limites ao poder secular, ora enfatizando a autoridade divina desse governo. Na segunda parte do já citado Da Autoridade Secular, o reformador se concentra em discorrer sobre o alcance dessa autoridade: “(...) temos que aprender agora qual é o alcance de seu braço e até onde se estende sua mão, para que não ultrapasse seus limites e interfira no reino e no regime de Deus". E então ele alerta que "resulta em dano insuportável e terrível quando se lhe abre espaço demais, sendo também prejudicial limitá-la em demasia." (LUTERO, 1996d, p. 97).

Sua defesa da liberdade de consciência o leva a confrontar príncipes e bispos para que "vejam quão insensatos são ao pretenderem, com suas leis e preceitos, forçar as pessoas a crerem desta ou daquela maneira". E mais, "quando se impõe uma lei humana à alma, exigindo que creia isto ou aquilo, como o quer a referida pessoa, é certo que ali não está a palavra de Deus." (LUTERO, 1996d, p. 97). Para Lutero, "a fé é um ato livre, ao qual não se pode forçar a ninguém." (LUTERO, 1996d, p. 99). Decorre dessa liberdade inerente à fé cristã a defesa luterana em favor da desobediência civil.

Se, pois, teu príncipe ou senhor temporal te ordenar que te coloques do lado do papa, ou que creias isto ou aquilo, ou se ordenar entregar livros, deves dizer-lhe: "Lúcifer não tem o direito de assentar-se ao lado de Deus. Amado senhor, é meu dever obedecer-vos com corpo e bens. Dai-me ordens na medida de vosso poder na terra, e obedecerei. Contudo, se me ordenais crer e entregar livros, não obedecerei. Pois neste caso sois tirano e vos excedeis. Dais ordens onde não tendes nem direito nem poder, etc.” Se, em conseqüência, te tira os bens e castiga essa desobediência, bemaventurado serás! Dá graças a Deus por seres digno de sofrer pela palavra e vontade divinas. Deixa este louco esbravejar. Ele encontrará seu juiz. Pois eu te digo: caso não te opuseres a ele e permitires que te tome a fé e os livros, certamente terás negado a Deus. (LUTERO, 1996d, p. 102). ${ }^{11}$

\footnotetext{
${ }^{11}$ As críticas de Lutero aos governantes não param por aí. Ele não se furta a denunciar, nessa obra, que "príncipe sábio é ave rara, e mais raro ainda um príncipe honesto. Em geral são os maiores tolos e os piores patifes da terra; por isso sempre tem que se esperar deles o pior e pouca coisa boa..." (LUTERO, 1996d, p. 103).
} 
Martinho Lutero defende abertamente a desobediência civil pacífica, ao mesmo tempo em que advoga a não resistência e a não violência contra a autoridade divinamente constituída, como ele insistentemente cita neste escrito, recorrendo sempre a Romanos 13, deixando clara essa dupla postura: "Ao mal não se deve resistir, mas tolerá-lo. No entanto, não se deve aprová-lo nem colaborar com ele ou seguir e obedecer-lhe sequer com um passo ou com um dedo." (LUTERO, 1996d, p. 102). Vemos aí um "agudo contraste entre os deveres da desobediência e da não-resistência à tirania.” (SKINNER, 2009, p. 299). Assim também, Roberto Zwetsch pondera que:

Lutero insistiu no direito da autoridade secular e como pessoas cristãs lhe deveriam respeitar e obedecer. Por outro lado, foi firme ao defender a liberdade de consciência e o direito do povo de resistir ao arbítrio toda vez que o governante ultrapassa o sentido de sua função pública. (ZWETSCH, 2016, p. 16).

Quentin Skinner endossa a percepção de que houve evolução no pensamento político de Lutero e a explica:

No começo da década de 1530, quando parecia provável que os exércitos do Império esmagassem a Igreja luterana, o reformador veio a mudar, súbita e definitivamente, suas idéias a respeito de questão assim crucial. Contudo, no decênio anterior, Lutero tinha uma razão específica para insistir ao máximo na doutrina da não-resistência: ele temia, com os demais reformadores, que seu clamor por mudanças na religião fosse desacreditado devido a uma associação com o radicalismo político. Foi isso o que o levou a emitir a Sincera advertência, de 1522, que dirigiu a "todos os cristãos", alertando-os "para que se acautel[ass]em contra a insurreição e a rebelião”. (SKINNER, 2009, p. 299-300).

Finalmente, Skinner destaca que a excessiva submissão do Lutero dos primeiros anos à autoridade constituída decorria de sua teologia, que enxergava na ordem social e política em curso resultado da "vontade e providência divina". Segundo esse autor, Martinho Lutero se valeu do Novo Testamento, notadamente da teologia paulina, como palavra final acerca da nossa conduta política. E, em seguida, "sustenta que a posição política prescrita no Novo Testamento consiste na plena submissão do cristão às autoridades seculares - ao mesmo tempo em que confere à gama desses poderes uma extensão crucial, fundando-os de modo tal que 
em nenhuma circunstância será legítimo opor-lhes qualquer resistência.” (SKINNER, 2009, p. 300-301).

\section{Conclusão}

Sobre a ética política de Martinho Lutero, parece-nos possível afirmar que podemos identificar no seu pensamento, em primeiro lugar, um claro ataque à autoridade papal e da Cúria, e suas pretensões de soberania universal sobre todas as instâncias, inclusive sobre o governo civil; em segundo lugar, uma clara defesa da autoridade secular e da obediência de todos a ela, inclusive da Igreja, mesmo quando se tratar de autoridade tirânica e injusta. Essa visão resulta de sua interpretação, dentre outros, do texto de Romanos 13. Em terceiro lugar, Lutero advoga a desobediência civil pacífica em casos de ameaça à fé e às Escrituras. E, por último, o reformador, numa patente mudança de pensamento, concorda com a reação armada contra as autoridades seculares quando estas usarem de violência contra os súditos e a fé evangélica estiver ameaçada de extinção. Como vimos, essa mudança ocorreu em face da iminência do ataque aos territórios luteranos pelas tropas imperiais.

Provavelmente, o momento mais delicado nessa trajetória é aquele que coloca o reformador de um lado e os camponeses de outro. Como visto acima, Lutero busca mediar o conflito com uma Exortação à Paz. Para alguns, ele poderia ser responsabilizado pela insurgência do campesinato. Ora, havia sido Lutero que com seus ensinamentos e exemplo teria aberto as portas para os revoltosos. Assim, ele poderia muito bem ser visto como o patrono do movimento (FEBVRE, 2012, p. 262). Mas, em sua tentativa de conciliação das facções, Lutero não deixa dúvidas sobre seu posicionamento. Ele não defende a revolta, ao contrário, prega a obediência. Em resposta ao argumento de que as autoridades eram perversas, diz Lutero que "o fato da autoridade ser perversa e injusta não justifica desordem e tumulto.” (LUTERO, 1996f, p. 314). Martinho Lutero reage especialmente ao uso que os camponeses estavam fazendo da Bíblia para embasarem suas reivindicações. 
Então, com base nas Escrituras, ele insiste com eles que "Cristo diz que não se deve resistir a nenhum mal e injustiça, mas sempre ceder, sofrer e permitir que sejamos despojados de nossos bens." (LUTERO, 1996f, p. 317). É bem verdade que no mesmo texto Lutero insta com os nobres a reverem seu posicionamento tirânico e injusto. Para ele, alguns dos doze artigos apresentados pelos camponeses "são tão justos e procedentes que desmascaram a vocês perante Deus e o mundo...” (LUTERO, 1996f, p. 311). Lutero insiste que "a autoridade não foi instituída para arrancar vantagens de seus súditos e explorá-los, mas para procurar seu bem-estar e o que é melhor para eles.” (LUTERO, 1996f, p. 312).

A partir do que foi exposto, não sabemos se o Lutero de fins dos anos de 1530 teria se posicionado de forma mais contundente ao lado dos camponeses. Esta é uma suposição que não pode ser objetivamente verificada. Como foi dito anteriormente, Lutero defendeu a posição que ele tomou no Contra as Hordas Salteadoras e Assassinas dos Camponeses. Mas, vale relembrar que seu pensamento político evoluiu, abrindo possibilidades de resistência e luta contra autoridades tirânicas. Mesmo que essa resistência estivesse relacionada à ameaça à fé cristã, é significativa sua nova tomada de posição.

\section{REFERÊNCIAS}

ALTMANN, Walter. Lutero e Libertação. São Paulo: Ática, 1994.

BURGARD, Peter J. Retórica Magistral - a lógica da autoridade e da sujeição em Lutero. In: HELMER, Christine (Ed.). Lutero - um teólogo para os tempos modernos. São Leopoldo: Sinodal, 2013.

DREHER, Martim N. História do Povo de Deus - uma leitura latino-americana. São Leopoldo: Sinodal, 2013.

DREHER, Martim N. Martinho Lutero (1483-1546) e Tomás Müntzer (1489-1525): A justificação teológica da autoridade secular e da revolução política. VERITAS, Porto Alegre, v. 51, n. 3, 2006, p. 145-168.

DREHER, Martin N. De Luder a Lutero, uma biografia. São Leopoldo: Sinodal, 2014. 
DUCHROW, Ulrich. Os Dois Reinos - uso e abuso de um conceito teológico luterano. São Leopoldo: Sinodal, 1987.

FEBVRE, Lucien. Martinho Lutero, um destino. São Paulo: Três Estrelas, 2012.

FISCHER, Joachim H. Introdução. In: LUTERO, Martinho. Debate Circular Sobre Mt 19.21. In: Martinho Lutero - Obras Selecionadas - v. 6, Ética. São Leopoldo: Sinodal, Porto Alegre: Concórdia, 1996.

JUNGHANS, Helmar. Temas da Teologia de Lutero. São Leopoldo: Sinodal, 2001.

LIENHARD, Marc. Martim Lutero - tempo, vida e mensagem. São Leopoldo: Sinodal, 1998.

LUTERO, Martinho. À Nobreza Cristã da Nação Alemã, acerca da melhoria do estamento cristão. In: Martinho Lutero - Obras Selecionadas - v. 2. O programa da Reforma, Escritos de 1520. São Leopoldo: Sinodal, Porto Alegre: Concórdia, 2000 .

LUTERO, Martinho. Adendo: Contra as Hordas Salteadoras e Assassinas dos Camponeses. In: Martinho Lutero - Obras Selecionadas - v. 6, Ética. São Leopoldo: Sinodal, Porto Alegre: Concórdia, 1996a.

LUTERO, Martinho. Advertência do Dr. Martinho Lutero a seus Estimados Alemães. In: Martinho Lutero - Obras Selecionadas - v. 6, Ética. São Leopoldo: Sinodal, Porto Alegre: Concórdia, 1996b.

LUTERO, Martinho. Carta aos Príncipes da Saxônia sobre o Espírito Revoltoso. In:

Martinho Lutero - Obras Selecionadas - v. 6, Ética. São Leopoldo: Sinodal, Porto Alegre: Concórdia, 1996c.

LUTERO, Martinho. Da Autoridade Secular, até que ponto se lhe deve obediência. In:

Martinho Lutero - Obras Selecionadas - v. 6, Ética. São Leopoldo: Sinodal, Porto Alegre: Concórdia, $1996 \mathrm{~d}$.

LUTERO, Martinho. Debate Circular Sobre Mt 19.21. In: Martinho Lutero - Obras Selecionadas - v. 6, Ética. São Leopoldo: Sinodal, Porto Alegre: Concórdia, 1996e.

LUTERO, Martinho. Debate para o Esclarecimento do Valor das Indulgências. In: Martinho Lutero - Obras Selecionadas - v. 1, Os Primórdios, Escritos de 1517 a 1519. São Leopoldo: Sinodal, Porto Alegre: Concórdia, 1987.

LUTERO, Martinho. Exortação à Paz: Resposta aos Doze Artigos do Campesinato da Suábia. In: Martinho Lutero - Obras Selecionadas - v. 6, Ética. São Leopoldo: Sinodal, Porto Alegre: Concórdia, $1996 f$.

LUTERO, Martinho. Tratado de Martinho Lutero sobre a Liberdade Cristã. In: Martinho Lutero - Obras Selecionadas - v. 2, O programa da Reforma, Escritos de 1520. São Leopoldo: Sinodal, Porto Alegre: Concórdia, 200ob. 
LUTERO, Martinho. Um Conselho do Doutor Martinho Lutero se é permitido resistir com razão ao imperador se ele quer usar de violência contra alguém por causa do Evangelho. In: Martinho Lutero - Obras Selecionadas - v. 6, Ética. São Leopoldo: Sinodal, Porto Alegre: Concórdia, 1996g.

MCGRATH, Alister. A Revolução Protestante - uma provocante história do protestantismo contada desde o século 16 até os dias de hoje. Brasília: Editora Palavra, 2012.

RANDELL, Keith. Lutero e a Reforma Alemã. São Paulo: Ática, 1995.

SKINNER, Quentin. As Fundações do Pensamento Político Moderno. São Paulo: Companhia das Letras, 2009.

ZWETSCH, R. Lutero, Justiça Social e Poder Político Aproximações teológicas a partir de alguns de seus escritos. Cadernos de Teologia Pública, São Leopoldo, v.13, n.133, 2016. Disponível em:

<http://www.ihu.unisinos.br/images/stories/cadernos/teopublica/113_cadernosteologiap ublica.pdf>. Acesso: 24 nov. 2016. 